\title{
Analysis of Plasmodium falciparum erythrocyte membrane protein 1- DBL $\alpha$ domain variants with respect to antigenic variations and docking interaction analysis with glycosaminoglycans
}

\author{
Deepti Deobagkar ${ }^{1,2^{*}}$, Aarti Ozarkar', Shipra Gupta², Megha Agrawal², Dileep Deobagkar \\ From Challanges in malaria research: Core science and innovation \\ Oxford, UK. 22-24 September 2014
}

\section{Background}

The variant surface antigen PfEMP1 (Plasmodium falciparum erythrocyte membrane protein 1) encoded by the polymorphic multi-copy var gene family plays an important role in parasite biology and the host-parasite interactions. Sequestration and antigenic variation is an essential component in the survival and pathogenesis of Plasmodium falciparum and contributes to chronic infection . The DBL $\alpha$ domain of PfEMP1 is a potential target for immuno-epidemiological studies and has been visualized as a vaccine candidate against severe malaria. Extensive var gene diversity (DBLa domain of PfEMP1) is an important aspect of pathogenesis in parasite lines. Specific host receptors like heparin, heparan sulphate, blood group A and complement receptor 1 have been reported to bind DBL $\alpha$ domain. Although heparin has been experimentally shown to disrupt the parasite-host interaction and effectively disrupt rosetting, the binding sites for the DBL $\alpha$ domain and mechanism behind heparin-mediated rosette inhibition have not been elucidated.

\section{Materials and methods}

3D structures and epitopes of DBL $\alpha$ domain in 3D7 and in two parasite isolates have been predicted and compared. Docking studies on DBL $\alpha$ domains with human GAG receptors (heparin and heparan sulphate) to predict the strength of association between the protein-ligand interactions were performed.

\section{Results}

The DBL $\alpha$ domain structures showed extensive diversity and polymorphism in their binding sites. The linear as well as conformational epitope prediction analysis predicted several B cell epitopes at variable positions in different DBL $\alpha$ domain variants [1]. The docking results indicate that heparin binds more effectively with high affinity as compared to heparan sulphate with some common interacting residues [2]. These common residues can play an important role in rosetting and will aid in the designing of inhibitors specific to the interactions between DBL $\alpha$ and heparin or heparan sulphate would be important in malaria treatment.

\section{Conclusions}

Thus such an analysis may lead to the development of novel interference strategies to block red blood cell invasion and provide protection against malaria and provide an insight into the complexities of host parasite interactions.

\footnotetext{
Authors' details

'University of Pune, Zoology Department, Pune, India. ' $U$ niversity of Pune, Bioinformatics Centre, Pune, India.

Published: 22 September 2014

\section{References}

1. Ozarkar AD, Prakash D, Deobagkar DN, Deobagkar DD: Prediction of B cell and $T$ cell epitopes of DBLalpha domain in Plasmodium falciparum malaria vaccine candidate var gene. Protein Pept Lett 2007, 14:528-530.

2. Agrawal MR, Ozarkar AD, Gupta S, Deobagkar DN, Deobagkar DD: Comparative study of Plasmodium falciparum Erythrocyte Membrane
} 
Protein 1- DBLa domain variants with respect to antigenic variations and docking interaction analysis with glycosaminoglycans. Molecular Biosystems 2014.

doi:10.1186/1475-2875-13-S1-P104

Cite this article as: Deobagkar et al:: Analysis of Plasmodium falciparum erythrocyte membrane protein 1- DBL $\alpha$ domain variants with respect to antigenic variations and docking interaction analysis with glycosaminoglycans. Malaria Journal 2014 13(Suppl 1):P104.

Submit your next manuscript to BioMed Central and take full advantage of:

- Convenient online submission

- Thorough peer review

- No space constraints or color figure charges

- Immediate publication on acceptance

- Inclusion in PubMed, CAS, Scopus and Google Scholar

- Research which is freely available for redistribution

Submit your manuscript at www.biomedcentral.com/submit
C Biomed Central 